\title{
Estimation of Heavy Metal Accumulation in Seeds of Leucaena leucocephala, Toona ciliata and Dalbergia sissoo Collected from Different Sites in Baddi Barotiwala and Nalagarh (BBN) Industrial Area of Himachal Pradesh
}

\author{
Nitika Sharma $^{1 *}$ and Mohinder Singh ${ }^{2}$ \\ ${ }^{1}$ Department of Environmental Science, ${ }^{2}$ Department of Entomology, Dr Y S Parmar \\ University of Horticulture and Forestry, Nauni, Solan, Himachal Pradesh, India \\ *Corresponding author
}

\begin{abstract}
A B S T R A C T
Keywords

Heavy metals, Seeds,

Tree species, Icap

Spectrophotometer

Article Info

Accepted:

16 August 2018

Available Online:

10 September 2018

Heavy metal is a general technical term that applies to the group of metals and metalloids with density greater than $4 \pm 1 \mathrm{~g} \mathrm{~cm}^{-3}$ or elements having atomic weight more than 20 . Heavy metals are considered toxic to living organisms and even trace metals that are considered essential for life can be toxic when present at excessive level, impair important biochemical process and also pose threat to human health, plant growth and animal life. The heavy metals, As, $\mathrm{Cd}, \mathrm{Cr}, \mathrm{Ni}$ and $\mathrm{Pb}$ were found accumulated in seeds collected from various sites. Higher concentrations of $\mathrm{Pb}$ were found in seeds of L. leucocephala collected from National Highway 21-A $(2.650 \mathrm{mg} / \mathrm{Kg})$, Baddi Barotiwala link road $(1.35 \mathrm{mg} / \mathrm{Kg})$ and Kalka Charnia link road $(1.195 \mathrm{mg} / \mathrm{Kg})$ against control $(0.960 \mathrm{mg} / \mathrm{Kg})$. Ni was recorded in higher quantities in seeds of $T$. ciliata and $D$. sissoo collected from roadside sites as compared to control.

\section{Introduction}

Heavy metal occurs as a natural constituent of earth's crust and is also released due to human activities. These also exist as ores in different chemical forms from which they are recovered as minerals (An et al., 2004). Heavy metal is a general technical term that applies to the group of metals and metalloids with density greater than $4 \pm 1 \mathrm{~g} \mathrm{~cm}-3$ or elements having atomic weight more than 20. Heavy metals have long biological half-lives and most of

them are extremely toxic because of their solubility in water (Moya et al., 1993). They are generally added to environment through automobile exhaust (Lagerwerff and Specht, 1970). Appreciable amount of gaseous and particulate heavy metals $(\mathrm{Fe}, \mathrm{Pb}, \mathrm{Cr}, \mathrm{Cd})$ are also added to the environment by industrial emission (Gupta et al., 2011). Heavy metals are considered toxic to living organisms and even trace metals that are considered essential for life can be toxic when present at excessive level, impair important biochemical process
\end{abstract}


and also pose threat to human health, plant growth and animal life (Morrinson et al., 1990). Deposition of lead on the vegetation growing along the road not only affects growth and germination but also causes a significant reduction in seed and fruit production of plants (Nassralla and Ali, 1985). Trees in cities are subjected to widespread pressure, which suppresses performance and shortens life span of trees (Gilbertson and Bradshaw, 1985).

\section{Materials and Methods}

The study was conducted in Baddi Barotiwala and Nalagarh (BBN) industrial area located in the foothills of Shiwalik hills. The study area lies on the border of Himachal Pradesh and Haryana states. Baddi, Barotiwala and Nalagarh area has emerged as a major industrial hub in Himachal Pradesh, situated in south west region of Solan and is about $45 \mathrm{~km}$ from Solan. The study area is situated at an altitude of $422-448 \mathrm{~m}$ above mean sea level and lies between $30^{\circ} 55^{\prime}$ to $31^{\circ} 02^{\prime} \mathrm{N}$ latitude and $76^{\circ} 42^{\prime}$ to $76^{\circ} 49^{\prime}$ E longitude.

In order to study the vegetation distribution, amount of pollution and to select the study sites a survey was conducted in the region. Based on the survey four sites selected for study were as National Highway $21 \mathrm{~A}$; in Baddi industrial area, Baddi-Barotiwala Link Road, Kalka-Charnia Link Road, Control; 200m away from road in Kalka-Charnia Link Road.

As control, the non-polluted agricultural area surrounding Kalka-Charnia link road was purposefully considered. Based on the vegetation distribution three commonly occurring tree species were selected in all the four sites for study. The tree species selected were Toona ciliata (Roem.) Leucaena leucocephala (Lamk.) and Dalbergia sissoo (Roxb.)
The seeds collected from selected sites of all the identified species were analysed for presence of heavy metals in the laboratory. The seed samples of different tree species were oven dried at temperature of $69^{\circ} \mathrm{C}$ for 10-15 days and then were powdered with the help of pestle and mortar. From each treatment $0.5 \mathrm{~g}$ of powder was measured and transferred to $100 \mathrm{ml}$ conical flask separately. For its digestion, nitric acid and per chloric acid were mixed in the ratio of $3: 1$ and $10 \mathrm{ml}$ of this mixture was added to each flask. The flasks were kept overnight for predigestion of samples. For digestion, flasks were placed on hot plate at temperature of $220^{\circ} \mathrm{C}$ for $2-4$ hours. Digestion of samples was considered completed when transparent color appeared. Then these samples were kept in laboratory overnight and next day $10 \mathrm{ml}$ of distilled water was added to each sample and filtered using whatman filter paper no. 1 and then samples were stored. After some days, total of $50 \mathrm{ml}$ volume was made by adding distilled water in bottles and then again samples were filtered. The estimation of heavy metals was done by using Inductively Coupled Absorption Plasma Spectrophotometer (Model - icap 6300 DUO) of thermo scientific make.

\section{Statistical analysis}

The experiment was carried out at Department of Environmental Science, Dr Y. S. Parmar University of Horticulture and Forestry, Nauni, Solan from April 2014 to April 2015. The experiment was planned as a completely randomized design with 5 replications.

\section{Results and Discussion}

Accumulation of heavy metals in the seeds of $L$. leucocephala collected from different sites

The quantities of As accumulated in the seeds of L. leucocephala collected from Kalka 
Charnia link road, Baddi Barotiwala link road and National Highway 21-A were 0.018, 0.036 and $0.052 \mathrm{mg} \mathrm{kg}{ }^{-1}$, respectively, whereas, no As accumulation was found in seeds collected from control site. All the sites differed with each other with respect to As accumulation.

The accumulation of $\mathrm{Cd}$ in L. leucocephala seeds was $0.060,0.050$ and $0.036 \mathrm{mg} \mathrm{kg}^{-1}$ in National Highway 21-A, Baddi Barotiwala link road and Kalka Charnia link road, respectively, against $0.030 \mathrm{mg} \mathrm{kg}^{-1}$ in control. No significant differences in accumulation of $\mathrm{Cd}$ in seeds collected from different sites were observed.

The quantity of $\mathrm{Cr}$ accumulated in the seeds of L. leucocephala was lowest in control site $\left(0.755 \mathrm{mg} \mathrm{kg}^{-1}\right)$ which was followed by Kalka Charnia link road and Baddi Barotiwala link road with 0.960 and $1.120 \mathrm{mg} \mathrm{kg}^{-1}$, respectively, against highest accumulation of $1.125 \mathrm{mg} \mathrm{kg}^{-1}$ in National Highway 21-A (Table 1). The concentrations of $\mathrm{Cr}$ in seeds collected from Baddi Barotiwala link road were also at par with National Highway 21-A.

The highest accumulation of $\mathrm{Ni}$ in the Leucaena seeds were also recorded in in National Highway 21-A which was $0.705 \mathrm{mg}$ $\mathrm{kg}^{-1}$ followed by Baddi Barotiwala link road and Kalka Charnia link road with 0.230 and $0.230 \mathrm{mg} \mathrm{kg}^{-1}$, respectively, against $0.185 \mathrm{mg}$ $\mathrm{kg}^{-1}$ of $\mathrm{Ni}$ accumulated in control site. $\mathrm{Ni}$ accumulation in Leucaena seeds was similar in Kalka Charnia link road and Baddi Barotiwala link road.

The accumulation of $\mathrm{Pb}$ in seeds collected from different sites was 2.650, 1.135 and $1.195 \mathrm{mg} \mathrm{kg}^{-1}$ in seeds collected from National Highway 21-A, Baddi Barotiwala link road and Kalka Charnia link road respectively, against $0.960 \mathrm{mg} \mathrm{kg}^{-1}$ in seeds collected from control site. Significantly highest concentration of $\mathrm{Pb}$ was recorded in seeds collected from National Highway 21-A.

Accumulation of heavy metals in the seeds of $T$. ciliata collected from different sites

The accumulation of As in the seeds of $T$. ciliata was significantly lowest in control site (0.005 $\mathrm{mg} \mathrm{kg}^{-1}$ ) followed by Kalka Charnia link road and Baddi Barotiwala link road with 0.035 and $0.050 \mathrm{mg} \mathrm{kg}^{-1}$, respectively, against highest accumulation of $0.085 \mathrm{mg} \mathrm{kg} \mathrm{kg}^{-1}$ in National Highway 21-A (Table 2). Accumulation of As in seeds collected from Kalka Charnia link road and Baddi Barotiwala link road was at par with each other. Significantly highest quantities of As were accumulated in seeds collected from National Highway 21-A.

The quantities of $\mathrm{Cd}$ accumulated in $T$. ciliata seeds were $0.315,0.345$ and $0.350 \mathrm{mg} \mathrm{kg}^{-1}$ in seeds collected from Kalka Charnia link road and Baddi Barotiwala link road and National Highway 21-A, respectively, against $0.275 \mathrm{mg}$ $\mathrm{kg}^{-1}$ in control site. The accumulation of $\mathrm{Cd}$ in the seeds was highest in National Highway 21-A which was also at par with Baddi Barotiwala link road.

Similarly, the amount of $\mathrm{Cr}$ accumulated in seeds was also highest in National Highway 21-A (1.120 mg kg-1), followed by Baddi Barotiwala link road and Kalka Charnia link road with 1.020 and $0.990 \mathrm{mg} \mathrm{kg}^{-1}$ of $\mathrm{Cr}$ accumulated against $0.850 \mathrm{mg} \mathrm{kg}^{-1}$ in control site. The concentrations of $\mathrm{Cr}$ in seeds collected from Baddi Barotiwala link road and Kalka Charnia link road were at par with each other.

The data on accumulation of $\mathrm{Ni}$ in $T$. ciliata seeds collected from different sites as presented in Table 2 revealed lowest concentration of $\mathrm{Ni}$ accumulated in seeds in control site i.e. $2.970 \mathrm{mg} \mathrm{kg}^{-1}$. 
Table.1 Accumulation of heavy metals in the seeds of Leucaena leucocephala Collected from different sites

\begin{tabular}{|l|c|c|c|c|c|}
\hline \multicolumn{1}{|c|}{ Treatment } & \multicolumn{5}{|c|}{ Heavy metals accumulated in seeds $\left(\mathrm{mg} \mathrm{kg}^{-1}\right)$} \\
\hline & $\mathbf{A s}$ & $\mathbf{C d}$ & $\mathbf{C r}$ & $\mathbf{N i}$ & $\mathbf{P b}$ \\
\hline $\begin{array}{l}\text { National } \\
\text { Highway 21-A }\end{array}$ & 0.052 & 0.060 & 1.125 & 0.705 & 2.650 \\
\hline $\begin{array}{l}\text { Baddi } \\
\text { Barotiwala link } \\
\text { road }\end{array}$ & 0.036 & 0.050 & 1.120 & 0.230 & 1.135 \\
\hline $\begin{array}{l}\text { Kalka Charnia } \\
\text { link road }\end{array}$ & 0.018 & 0.036 & 0.960 & 0.230 & 1.195 \\
\hline \begin{tabular}{l} 
Control \\
\hline C.D
\end{tabular} & 0.000 & 0.030 & 0.755 & 0.185 & 0.960 \\
\hline
\end{tabular}

Table.2 Accumulation of heavy metals in the seeds of Toona ciliata Collected from different sites

\begin{tabular}{|c|c|c|c|c|c|}
\hline \multirow[t]{2}{*}{ Treatment } & \multicolumn{5}{|c|}{ Heavy metals accumulated in seeds ( $\left.\mathrm{mg} \mathrm{kg}^{-1}\right)$} \\
\hline & As & Cd & $\mathrm{Cr}$ & $\mathbf{N i}$ & $\mathbf{P b}$ \\
\hline $\begin{array}{l}\text { National } \\
\text { Highway 21-A }\end{array}$ & 0.085 & 0.350 & 1.120 & 3.200 & 2.155 \\
\hline $\begin{array}{l}\text { Baddi } \\
\text { Barotiwala link } \\
\text { road }\end{array}$ & 0.050 & 0.345 & 1.020 & 3.190 & 1.640 \\
\hline $\begin{array}{l}\text { Kalka Charnia } \\
\text { link road }\end{array}$ & 0.035 & 0.315 & 0.990 & 3.080 & 1.620 \\
\hline Control & 0.005 & 0.275 & 0.850 & 2.970 & 1.455 \\
\hline C. $D_{(p=0.05)}$ & 0.018 & 0.008 & 0.081 & 0.011 & 0.015 \\
\hline
\end{tabular}

Table.3 Accumulation of heavy metals in the seeds of Dalbergia sissoo Collected from different sites

\begin{tabular}{|c|c|c|c|c|c|}
\hline \multirow[t]{2}{*}{ Treatment } & \multicolumn{5}{|c|}{ Heavy metals accumulated in seeds ( $\mathrm{mg} \mathrm{kg}^{-1}$ ) } \\
\hline & As & Cd & $\mathrm{Cr}$ & Ni & $\mathbf{P b}$ \\
\hline $\begin{array}{l}\text { National } \\
\text { Highway 21-A }\end{array}$ & 0.200 & 0.230 & 1.455 & 3.045 & 1.930 \\
\hline $\begin{array}{l}\text { Baddi } \\
\text { Barotiwala link } \\
\text { road }\end{array}$ & 0.045 & 0.200 & 1.365 & 2.655 & 1.765 \\
\hline $\begin{array}{l}\text { Kalka Charnia } \\
\text { link road }\end{array}$ & 0.015 & 0.125 & 1.255 & 2.360 & 1.580 \\
\hline Control & 0.015 & 0.125 & 1.030 & 1.670 & 1.245 \\
\hline C.D $(p=0.05)$ & 0.011 & 0.013 & 0.012 & 0.011 & 0.018 \\
\hline
\end{tabular}


Table.4 Comparative concentrations of $\mathrm{Pb}$ and $\mathrm{Cd}$ in seeds of various tree species Collected from different sites

\begin{tabular}{|l|c|c|c|c|c|c|}
\multicolumn{2}{|c|}{ Sites } & \multicolumn{2}{|c|}{ L. leucocephala } & \multicolumn{2}{c|}{ T. ciliata } & \multicolumn{2}{c|}{ D. sissoo } \\
\cline { 2 - 8 } & Pb & Cd & Pb & Cd & Pb & Cd \\
\hline $\begin{array}{l}\text { National Highway } \\
\text { 21-A }\end{array}$ & 2.650 & 0.060 & 2.155 & 0.350 & 1.930 & 0.230 \\
\hline $\begin{array}{l}\text { Baddi Barotiwala } \\
\text { link road }\end{array}$ & 1.135 & 0.050 & 1.640 & 0.345 & 1.765 & 0.200 \\
\hline $\begin{array}{l}\text { Kalka Charnia link } \\
\text { road }\end{array}$ & 1.195 & 0.036 & 1.620 & 0.315 & 1.580 & 0.125 \\
\hline Control & 0.960 & 0.030 & 1.455 & 0.275 & 1.245 & 0.125 \\
\hline C.D $(\mathrm{p}=0.05)$ & 0.019 & NS & 0.015 & 0.008 & 0.018 & 0.013 \\
\hline
\end{tabular}

$\mathrm{Ni}$ accumulated in Kalka Charnia link road, Baddi Barotiwala link road and National Highway 21-A was 3.080, 3.190 and 3.200 $\mathrm{mg} \mathrm{kg}{ }^{-1}$ respectively. The accumulation of $\mathrm{Ni}$ in seeds collected from National Highway 21A and Baddi Barotiwala link road was at par with each other.

The accumulation of $\mathrm{Pb}$ in seeds collected from different sites was $2.155,1.640$ and $1.620 \mathrm{mg} \mathrm{kg} \mathrm{kg}^{-1}$ in seeds collected from National Highway 21-A, Baddi Barotiwala link road and Kalka Charnia link road, respectively, against $1.455 \mathrm{mg} \mathrm{kg}^{-1}$ in seeds collected from control site. All the sites differed in accumulation of $\mathrm{Pb}$ in seeds with each other with highest accumulation in National Highway 21-A.

Accumulation of heavy metals in the seeds of $D$. sissoo collected from different sites

The amount of As accumulated in the seeds of D. sissoo was lowest in control site $(0.015 \mathrm{mg}$ $\left.\mathrm{kg}^{-1}\right)$. As accumulated in seeds collected from Kalka Charnia link road, Baddi Barotiwala link road and National Highway 21-A was $0.015,0.045$ and 0.200 , respectively (Table $3)$. The accumulation of As was highest in National Highway 21-A. As accumulated in Kalka Charnia link road was similar to control site.
The accumulation of $\mathrm{Cd}$ in $D$. sissoo seeds was $0.125,0.200$ and $0.230 \mathrm{mg} \mathrm{kg}^{-1}$ in Kalka Charnia link road, Baddi Barotiwala link road and National Highway 21-A respectively, against $0.125 \mathrm{mg} \mathrm{kg}^{-1}$ in control site. The accumulation of $\mathrm{Cd}$ was also highest in National Highway 21-A. The seeds collected from Kalka Charnia link road accumulated same quantity of $\mathrm{Cd}$ as in control site.

The accumulation of $\mathrm{Cr}$ in the seeds of $D$. sissoo was also highest in National Highway 21-A (1.455 mg kg $\mathrm{mg}^{-1}$ ), followed by Baddi Barotiwala link road and Kalka Charnia link road with 1.365 and $1.255 \mathrm{mg} \mathrm{kg} \mathrm{kg}^{-1}$, respectively, against $1.030 \mathrm{mg} \mathrm{kg}^{-1}$ in control site (Table 3).

The data on accumulation of $\mathrm{Ni}$ in the seeds of D. sissoo collected from different sites as presented in Table 3 revealed lowest concentration of $\mathrm{Ni}$ in seeds collected from control i.e. $1.670 \mathrm{mg} \mathrm{kg}^{-1}$. The seeds collected from National Highway 21-A, Baddi Barotiwala link road and Kalka Charnia link road accumulated i.e. 3.045, 2.655 and 2.360 $\mathrm{mg} \mathrm{kg}{ }^{-1}$ of Ni respectively. Ni accumulation in seeds differed significantly between sites.

The $\mathrm{Pb}$ accumulated in seeds of $D$. sissoo collected from different sites was 1.930, 1.765 and $1.580 \mathrm{mg} \mathrm{kg}^{-1}$ in seeds collected from 
National Highway 21-A, Baddi Barotiwala link road and Kalka Charnia link road respectively, against $1.245 \mathrm{mg} \mathrm{kg}^{-1}$ in seeds collected from control site. The seeds collected from all roadside trees of $D$. sissoo accumulated higher quantities of $\mathrm{Pb}$ as compared to control with highest accumulation of $\mathrm{Pb}$ in National Highway 21A (Table 4).

The lead $(\mathrm{Pb})$ and Cadmium $(\mathrm{Cd})$ are an important toxic pollutant added to the environment through auto-exhaust (Lagerwerff and Specht, 1970).

Higher concentrations of lead have been reported in plants growing in polluted areas (Asgar, 2004; Naveed et al., 2010). Mahmood and Iqbal (1989) have reported that seeds of A. lebbeck and D. sissoo from polluted areas showed significant reductions in seed germination due to presence of lead.

In the studies also higher concentrations of lead have been observed in seeds of $L$. leucocephala collected from polluted areas than control (non-polluted areas). Highest lead accumulation in seeds was recorded in National Highway 21-A site, where reduction in seed germination was also highest.

These findings may validate the role of lead in affecting seed germination in roadside trees. The reductions in seed germination of L. leucocephala due to lead have also been reported by Iqbal et al., 2001. Higher concentrations of nickel (Ni) have been recorded in seeds of $T$. ciliata and $D$. sissoo that may be attributed to industrial pollution as entire study area falls under important industrial hub of Himachal Pradesh.

\section{Acknowledgements}

The authors are thankful to Dr Y. S. Parmar University of Horticulture and Forestry
Nauni, Solan, Department of Environmental Science for providing all the facilities to perform the study.

\section{References}

An Y J, Kim Y M, Kwon T I and Leong S W, 20 Combined effects of copper cadmium and lead upon cucumis sativus growth and bioaccumulation. Science of Total Environment, 2004, 326: 85-93.

Asghar R, The Effect of auto-exhaust pollution on the growth of roadside plants in twin cities, Rawalpindi and Islamabad, Pakistan. Sarhad Journal of Agriculture, 2004, 20(3): 415-418.

Gilbertson $\mathrm{P}$ and Bradshaw A D, Tree survival in cities, the extent and nature of the problem.Arboricultural Journal,1985, 9: 131-142.

Gupta S, Mondal D and Dutta J K, Anticipated performance index of some tree species considered for greenbelt development in an urban area. International research journal of plant science, 2011, 2(4): 99-106.

Iqbal M Z, Shafiq M and Kausar A S, Toxic effects of lead and cadmium individually and in combination on germination and growth of Leucaena leucocephala. Pakistan Journal of Botany, 2001, 33: 551-557.

Lagerwerff J W and Specht A W, Contamination of roadside and vegetation with Cadmium, nickel, lead and zinc. Environmental Science and Technology, 1970, 4: 583-586.

Mehmood M T and Iqbal M Z, Impact of vehicular emission on seed germination of some roadside trees. Pakistan Journal of Scientific and Industrial Research, 1989, 32: 752-753.

Morrinson G M P, Revitt D M and Ellis J B, Metal speciation in separate storm water system. Water Science and Technology, 1990, 22(10/11):53-60. 
Moya J L, Pos R and picazo I, Influence of cadmium and nickel on growth net photosynthesis and carbohydrate distribution in rice plants. Official Journal of the International Society of Photosynthesis Research, 1993, 36: 7580.

Nasralla M M and Ali E A, Lead accumulation in edible proteins of crops grown near Egyptian traffic roads.
Agriculture, Ecosystems and Environment, 1985, 13: 73-82.

Naveed N H, Batool A I, Rehman F U and Hameed Uzma, Leaves of roadside plants as bioindicator of traffic related lead pollution during different seasons in Sargodha, Pakistan. African Journal of Environmental Science and Technology, 2010, 4(11): 770-774.

\section{How to cite this article:}

Nitika Sharma and Mohinder Singh. 2018. Estimation of Heavy Metal Accumulation in Seeds of Leucaena leucocephala, Toona ciliata and Dalbergia sissoo Collected from Different Sites in Baddi Barotiwala and Nalagarh (BBN) Industrial Area of Himachal Pradesh. Int.J.Curr.Microbiol.App.Sci. 7(09): 2261-2267. doi: https://doi.org/10.20546/ijcmas.2018.709.280 